\title{
Harmonization and Reformation of the Fiscal System of the South Eastern Europe according to EU Principles
}

\author{
Dr.sc. Armand Krasniqi \\ Faculty of Economy-University of Prishtina \\ Email: mandikrasniqi@gmail.com
}

Doi:10.5901/ajis.2014.v3n4p65

\section{Abstract}

\begin{abstract}
Apart from positive developments and the effects of globalism mankind is being challenged by the negative phenomenon caused by a number of crisis. It is broadly known that the global economic crisis change always financial markets, and this situation is difficult to be overcome.Bu unfortunately this crisis is not the only one.There is of high social dangerousness the incrimina and the de-balance of the ecosystem. There is no dilemma that the natural resources are in a continual degradation and in a continual decrease and this should be for every country a signal as a need to enter into changes of the economic model and basic structures. Without any calculation, if the world policies quickly don't take measures to reduce the emission of CO2 to from $50-80 \%$ then the capabilities of limiting the global warm changes. Just because of this governments should be more responsible in order to create an economic more advanced model on the basis of sustaiable development.To realise this model there should be made a substantial reform of the fiscal system, as well. Legislative basis should be re-designed in that way that taxes, licences and other instruments to be compatibile with the concepts for a sustainable environment development. Within this activities the reformation of the system should be done on the basis of rules,principles,programs and procedures of relevant institutions of EU. Respect to this elements creates more possibilities for unification of fiscal systems that as the final goal have itself accession to this organization.
\end{abstract}

Keywords: Taxes,ecological, reform, sustainable, reform,economic Jel: K 0, K 32,

\section{Introduction}

EU fiscal system is important segment of vital importance in the way of advancing and guarantee of integration process of single market enabling a high level cohezion in sense of keeping of high level integration policies in EU.Structure of EU fiscal system is based on its budget as the only instrument to implement financial policies at the supranational level. The rest from the fiscal system is considered as a collection of rules and juridicial responsibilities through which member states make the harmonization and coordination of other segments of unilateral fiscal policies. EU currently appears as a unique institution aiming to realize values, interestes and goals for what indeed it is created being always coherent and efficient in function of concrete actions and policies. Fiscal rules in EU are based on the Mastricht criteria, Pact of Stability and they are also a product of monetary union with the final aim stabilization of prices. EU especially last years has undertaken a series of measures to eleminate harmful tax competition and other negative phenomenon that impact the strengthening the process of common market. Harmonization of fiscal forms in EU is realised only with the sphere of indirect taxes (VAT and excise), whereas the part of indirect taxes practically remains not harmonised withonly some temptations to regulate the tax in profit of enterprisses. The reason for this situation is reflection respectively current viewpoints that the substantial EU interest, is important that the engagement for harmonization of indirect taxes with the aim of function of common market and elimination of eventual indirect tax barriers connected to freedom of free circulation, capital, production, services, work,etc.

Kosova and other countries of south-east Europe with the characteristics of candidates for total membership in EU should undertake a series of activities and measures in a way that as quickly as possible to harmonize their legislation with the EU regulative. Of special importance within this process is considered to be the aproximation and unification of fiscal systems with directives, programs and other juridical resorces of EU. The aim of this paper is to offer initial information on the role, structure and importance of EU ecologic fiscal system proposing two esential issues. First, reforming of the fiscal system in sense os system structure and secon, completion of the legal basis through a series of measure that sautheastern Europe countries should undertake for membership in this organization without forgeting environment danger, actual globalization process, problems of international tax competition and multiple taxation in the international plan. 


\section{Environment Problems in the Modern Societies and Environment Culture}

Current environment problems are acumulated as never before and as such, with a dynamic trend still continue to characterise thi sphenomenon as a part of modern civilization. Environment problems almost worlwide are defined as "every change that happens in the physic environment as a result of activities of people that cause this situation and this causes consequences thta society considers unacceptable with the standards of a sustaiable environment". These problems can be identified from various viewpoints: at the global level when phenomenon of global warming and wheather, damage and damage of ozon layer in pollution of "acid rain", in the regional level, pollution of underground waters, naphta,flooding dhe local pollution of water, air and other types of insufficient storage of waste.

According Jens Hilgenberg the head of the Association for Environment and Protection of Nature in Germany (BUND) as a responsible activist alerts the the air posion is the biggest environment problem in Europe. According to him the gas emission (CO2) is the biggest problem of environment in the entire world. The fact that the quality of air causes further big concerns in Europe and this is seen in the published report by the European Agency for Environment, he claims. According to data from this agency, $90 \%$ of inhabitants of EU cities face acorn that are qualified as harmful by World Health Organization (WHO). The above mentioned explains through DW that in these acorns there are carbon dioxide and harmful gases and dusts. ${ }^{1}$

Formulation of environment culture is not an easy tesk to be created especially when we take into the consideration that these specific relations and social behaviour by decades are characterised as problematic. Therefore scientific disciplines begining with psychology should engage in order to find a suitable way for awareness on environment issues to increase at the future level.

Implementation of laws, application of sanctions and the citizen culture on protecting environment where we live is essential for our children and the future. Air,flora and fauna,forests, seas, lakes,etc., everything is being ruined more e more every day because of non implementation of laws and international conventions that our countries have ratified. To protect environment not only means to adopt laws but it is more essential to implement them. This is especially important for our country where because of the lack of law implementaion and non execution of sanctions a lot is being ruined and there is a lot being exploited in regard to nature.It is the duty of respective institutions to coordinate in order to protect strongly environment where they, their children and the entire people live. Subjects that violate these environment laws doesn't suffer anythig or they can even pay a symbolic penalty and thus they will continue with their profit activities because the respective authorities are not aware or they are not concrns about the caused damages in the nature. Our society maybe has many problems in the field of justice but I think that there is crucial to stay in this situation because it is the damage of the air we breath,water we drink,environment we live in every day and wehre our shildren grow. ${ }^{2}$

\section{EU Tax System}

Taxes are money collected based on the law from the physich and juridical persons and other categories of taxpayers that are used to guarantee financing of goods and public services needed through the institution of budget and other public funds.Public finances of eaxh country comprise from budget and a determined number of public funds. Collection of public funds is realised through a determined tax forms and other public incomes as customs, taxes, excises, compensations, taxes from stamps and other tax burdens-fiscal. While the part of budget imputs is comprised by totality of collected public means, the part of outputs is dedicated its expenditures.In the EU tax system, tax incomes are collected and they are spent from various levels of governance strating by local level, regional, national up to the supranationa.Collected public funds are spent through competent financial institutions on the basis of budgetary rules and respecive funds. ${ }^{3}$

Tax differences between member states of EU are solved at the moment when the issues of tarif barriers and remained non tarifs were regulated within the inner market in favor of developing of concepts of free comon market. Along with the instalation of the Custom Union, gradually are taken off prior custom barriers of inner markets and at the same time there were eliminated obstacles and other non custom barriers related to free movement of persons, goods, services and capital. But within EU member states there remained differences that were products of different tax

\footnotetext{
${ }^{1}$ Marrë në; http://www.dw.de/ndotja-e-ajrit-n\%C3\%AB-evrop\%C3\%AB/a-17171687 me 01.02.2014

${ }^{2}$ Arjana Kokonozi "Zbatimi i ligjit per mbrojtjen e mjedisit" IMIM marrë në http://www.justforumalbania.org/zbatimi-i-ligjit-per-mbrojtjen-e-mjedisit-t83.html

3 Këto burime ju referohen të dhënave të marra nga ueb - i si në vijim me darën 20.01.2014 http://ec.europa.eu/taxation_customs /taxation/gen_info/economic_analysis/tax_structures/index_en.htm
} 
structures,ways and goals of use of public means as well as a series of changes related to rules, technics, standards,etc., of state policies in this important segment.Apart of this, countries of EU differ also from the various level corruption phenomenon and informal economy thathave their effects at the both levels of structures of public finances and functioning of the segment of legal economy. ${ }^{4}$

In the European Union there are a lot of discussion aboutthe structure of taxes, partial harmonization of it an finding the possibilities for total harmonization. The debate itself in fact shows the complexicity of the fiscal system in the entire territory of Europe.

Even though a small result really is noted in the harmonization of the fiscal system in the territories of EU, there are not absent activities for finding og basis for policies and common fiscal system. EU fiscal policies ${ }^{5}$ are centralised and their character is national from the fact that taxes are stronly linked to member states. This because, with the exclusion of harmonisation of custom tarifs, the lowest norms of VAT and only some excises for determined products, the tax systems are put in the set of exclusive competences of member states. Up to date all efforts for EU equalisation of tax policies as well as efforts to transfer at least some taxes from the jurisdiction of EU institutions. Since EU is financed from member states, the governing institutions of EU have no legislative power. This means that EU is not able to decide, to impose and to collect taxes. ${ }^{6}$

\section{Eco - Taxes in EU}

Related to the term eco-tax the german economist Bank Frank Zipfel explains that this doesn't exist but it became to be a standard term that is used in the reform of ecological taxes. This term has started to be used during 60 -ies and 70 -ies of XX Century with the aim of renewing and strengthening of ecological awareness, especially in promoting the idea of Piguo for a taxation of external factors. The first wave of ecologic tax reform has not given the expected results based on the fact that the payment of ecological taxes was considered as a type of determined compensation or taxes for ecologic permission. Only at the end of 80-s the amount of eco taxes had increased and intensified giving to the issues the penal character. ${ }^{7}$ Green taxes, ecologic taxes or eco-taxes are incomes that are paid from the subjects that are qualified as pisoners of environment that with their activities have a negative impact in the living environment. These taxes are put within the fiscal system to decrease the appearance external effects aa it is pollution and usually as such are considered correcting instruments. They not only produce incomes and they help on the other site on linking of private stimulations on social benefits which have improving effect generally in the economic life. ${ }^{8}$ In reality concept of ecologic taxes in the literature is not detrmined officialy.However European Commission,Eurostat and OECD, ecologic taxes define from the aspect of determination of tax basis. According to them these forms of taxes that burden taxpayers based on the physich unit of substance ore materia that have negative impact in th eliving environment. All EU activities related to the green taxes retrospectively or perspectively are divided into six economic programs as follows: ${ }^{9}$

1) Ecologic Program I. (1973-1976), document that has determined green-ecological taxes in EU, in the direction of reducting pollution, improving the quality of life and improving the international cooperation in the field of environment protections;

2) Ecologic Program II. (1977-1981), document that has expanded the activity of the first document. The main focus of thsi program is based on prevention of pollution of water and air, prtection of forests and direction of rational governance with the natural resources.

3) Ecologic Program III. (1982-1986), document that considers with the priority the policies of living environment of people, reduction of noise, waste management, promotion of environment technologies, as well the establishment of cooperation with the countires in development in solving the problems inthe environment protection;

4) Ecologic Program IV. (1987-1992), document that covers also policies on environment in the field of agriculture and trade;

\footnotetext{
${ }^{4}$ Ibid.

${ }^{5}$ EU Fiscal Policy

${ }^{6}$ Këto burime ju referohen të dhënave të marra nga ueb -i si në vijim me darën 20.01.2014 http://ec.europa.eu/taxation_customs /taxation/gen_info/economic_analysis/tax_structures/index_en.htm

${ }^{7}$ Filipović, S., Ekonomski anali br 162, jul 2004. - Septembar 2004. fq.212.

${ }^{8}$ Stiglic, E. Joseph, Ekonomija javnog sektora, Ekonomski fakultet, Zagreb, 2004. fq 736-738.

9 EU Environmental Issues and Policies Guidelines marrë në http://www.ueapme.com/business-support\%20ll/Training\%20Tools /Confartigianato/Environment/EU\%20Environmental\%20Guide.pdf faqe 7, e shkarkuar me datën 08.02.2014
} 
5) Ecologic Program V. (1993-2000) document that initially has determined the basis of the concept for sustainable development whereas the programs of previoes phase are focused in the imporvement of environment and;

6) Ecologic Program VI. (2001-2010) is implemented by name "Our future our choise 2010" proposing five future priorities: improving existing legislation, cloe trade cooperation,integration of organs involved in the environmental policy, to help people to change their behavour and planification for environment protection. ${ }^{10}$

In EU there are three cathegories of environmental taxes: tax on energy, tax on transport, and a tax on pison of natural resources. ${ }^{11}$ On the producta of energy involve: taxes on mineral oil and motor oil, unleaded and other petrol, naphta, gas, has for consum for family consumtion and consum for energy.Tax on transport involves: registration and the use of motoric vehicles, tax for import and export on motoric means,taxes for use of roads and highways, luxury yachts and air traffic of passengers. Tax on pollution of natural resources cover: a tax on pesticides and artificial fertilizers, metalic packing,plastic,glass, ceramic,

Tatimi mbi ndotjen e burimeve natyrore përfshijnë: një taksë mbi pesticideve dhe plehrat artificiale, paketimit prej metali, plastike, qelqi, qeramika, waste (Landfill), air pollution (CO2, SO2, NOx), bateries, tires, containers at the disposal, (water protection) to lose water (inner or industrial),plastic bags, water pollution CFC, HFC, PFAC dhe SF6 (ozon pollutioners) and nuclear energy.

\section{Internationalization of Fiscal Approach on Eksternal Factors - Externality}

The issue of redunant gas emission in greenhouses and other high forms of environment pollution for economic developments not only were treated negatively but they are considered of high social dangerousness. Therefore externalities are factors or effects of negative or positive which a determined subject during development of aspecific activity, during the process of production or consmption causes to the other subject, as a result of the process of production or consumption and not from the mechanisms of prices.

Ecologic tax instruments by which the protection of environment is desired are divided into three groups:

1) Pigou -ecologic taxes tatimet are considered as specific entities of taxes where the burden is measured directly on the basis of pollution units which determined subjects emit.Differently by these taxes it is pretended the reduction of determined pollution through emission. In this issue it is essential the realization of Pigou bans respectively throgh these taxes the internalization of so called external costs that are reflected because the pollutioners of environment create against the third parties that are not at all involved in a specific market (example:citizens breathing polluted air have health problems). Therefore the cost of ecological tax should be a burden belonging to determined polluters an thus by this there are collected means that shoukd be oriented and spent for the benefit of improvement and valorization of natural resources. ${ }^{12}$

2) Pre Pigou Taxes are considered a group of instruments that are considered indirect taxes as for example: costum taxes, excises,etc. According to this by law tax norms by taxes are burdened goods and services that are considered that during production and consumption do not produce negative effects in the environment whereas when we talk for goods and services that have negative impact in polluting environment their undergo a specific regime of high taxation. ${ }^{13}$

3) Double ecologic tax is used on collection of incomes that are focused in exclusive determined activities on environment protection respectively in the projects to finance environment pollution. ${ }^{14}$

In general there are known three groups of instruments dedicated to environment policies. The firts they are instruments of command and control that directly regulate the prohibition or permission of products and services during implementation of human activities in general, the second they are economic instruments of regulation directly or indirectly (taxes,penalties, rewards,subventions,etc.,other forms of environment management and the third: voluntary instruments that derive from aspirations of producers,comsumers and state to promote ecologic equilibrum known as

\footnotetext{
${ }^{10}$ Po aty nga faqe 7 deri në faqen 9

${ }^{11}$ D. Pîrvu i E. Clipici, Perspectives of the Environmental Taxes Evolution in the European Union, The Romanian Economic Journal, No. 38., December, 2012., str. 147. - 161

12 John V. C. Nye - George Mason University / The Pigou Problem, marrë me 20.01.2014 në: http://object.cato.org/sites/cato.org/files/ serials/files/regulation/2008/6/v31n2-5.pdf

${ }^{13}$ Po aty

${ }^{14}$ Po aty
} 
integrated planification on the basis of sustaiable development, responsibility of producers during the life circle of product, agreements for the means of control,valuation of the situation of in the environment, the system of public information about the situation and the environmental problems. ${ }^{15}$

\section{Reforming, Harmonisation and the Tax Structure}

Harmonization of tax system involves a complicated process of synchronisation, coordination and unification of tax system between member states and pretendends for EU in order to eliminate national tax instruments which have negative impact on the function of the common market. Therefore this process usually is proposed to be built up on the institutional action principles that are interlinked qith the clarity, maturity, rightfullness, simplicity, unfailing, appropriateness, reliability, solidarity, efficiency, responsibility,etc. Thus based on these principles it comes that the aims of reform of ecological tax by all means should be real, reliable and establishe precisely whereas the public opinion should be informed. Creation of applying ecologic taxes should be done gradually without using the state instruments of force.On creating the system we should take care about the level, state,structure,etc.,economic, ecologic,edomgraphic,biregional,ethno-cultural, psycho-social situation.In special each undertaken act should be prudent and any kind of carelessness being heavy or easy, could cause serious problems losing in such way the authority of institutions. We should the possibilities so while implementing ecological taxes ecologic taxes to compensate them by the decrease of other taxes taking always care about the economic stability. If the ecologic taxes act regressively it is very neccessary planning for implementation of compensation measures.

Ecologic taxes should be simple so financial officials could implement them easily. The aim of as much as possible spreading the incomes then it is possible that the phneomenon of fiscal evasion wil appear.Because of this along with the mechanisms of paying we should work for increasing the awareness about the obligation that a subject has regarding this issue. Important element of every strategy for environment protection is the appropriateness of that comform the esence of economic development and environment changes. A sensible issue is considered to be the the precise determination of the ecologic tax level and the determination of taxpayers. The level of ecologic tax should not be detrmined arbitrarely and as a potentil lobbying process. Finally the success on implementation of these types of taxes depending on whether they are going to be qualified as taxes high-low or optimal.Among important elements of strategy should be their appropriateness in report with the dynamic of developments and socio-economic changes.From this, there is an obligation to make sure that while establishing these taxes the burden of general taxes doens't increase so the entire system is under the risk. Determination of the uper real level of ecological taxes and its suitability with the paying capacities of taxpayers is one of the most complicated issues. The real height of ecological tax and in no way should not be put arbitrarily of based on the pressure from the informal structures. It is uncontested that the process of reform of a system to be realised only in one country. Therefore in order to implement such projects there are needed engagements and actions of the international lavel respectively there should be solidarity. The principle of efficiency is interlinked to the aplication of ecological taxes only then if the damaged environmental resources are projects designed and prepared that could be implemented and implemented to ensure a secure and qualitative impact of development.Above all the entire activity of reform, harmonisation, ballancing respectively synchronisation of tax system including the eco-taxes should be realised with accountable professionalism that will derive a developmet result and effective and substantive environment. ${ }^{16}$ The South Eastern European countries that are at the determined levels of transition should also by all means to create needed institutional pre conditions for a successful implementation of a tax reform. In this function it is recommended that during this process there should be created and ensured macro-economic stability, the existence of the rule of law, the creation of a close technical-technological cooperation and partnership, substantial increase of management efficiency in the public sphere and increase of professionalism in guarding and valorisation of environment resources.

\section{Conclusions}

Since year 2008 Europe and almost the entire world is facing an economic and financial crisis. Starting as bank crisis the

${ }^{15} \mathrm{~J}$. Klarer e të tjerët : Sourcebook on Economic Instruments for Environmental Policy Central and Eastern Europe, The Regional Environmental Center for Central and Eastern Europe, Szentendre, Hungary, 2000., str. 23.

${ }^{16}$ European Environment Agency - Environmental tax reform in Europe: opportunities for eco-innovation, Luxembourg: Publications Office of the European Union, 2011 
crisis quickly became to be a financial crisis, crisis that caused a a fiscal stress from which not only European countries of not easily geting rid. This affected the engagement and orientation of countries in mobilization of financial means through stimulaton economic programs witgh the aim stabilization policies. It is interesting to see how speedy and forcefully reacted the governments of European states in order to face the crisis whereas it is very depressing how we are doing regarding the global pollution that is of high dangerousness. In this regard they deal with comodity whereas their concerns are expressed only declaratively.

Therefore the paper concludes that in EU and in the states that aspire integration their systems are characterised with emphasized similarities and diferences. Differences are evidented ingeneral income taxes, in structure, in norm and in the basis of their determination. Tax incomes in the modern world are neccessary in order to guarantee democracy , public order and functioning the juridicial system. They should be more than a simple income resource on functioning of the state, to guarantee also that the public authorities contribute actively realisation of policy goals in economy, society and in the environment. Taxes are important instruments on redistribution of incomes collected for the benefit of citizens. The guarantee of a cohesion and solidarity in society automatically requires transfers in the social mass where the tax need for this function has no alternative. Ecologic taxes, green taxes of the future are economic-juridicial instruments which are established by competent institutions with the aim of prevention, limitation and elimination of environment pollution. Modern policies of environment pollution should be created in the function of sustainable economic development, ecosystem, care for biodiversity and ecological ballance based on the fact that environment is the most important asset of people.

Establishing and implementation of ecologic taxes as instruments through which the realisation of goals of environment protection should be directed on the basis of equality principles and the tax justice because in a system of rule of law all subjects within judicial-tax relationships expect that the burden of taxes should be paid in the name of ecological tax that should be equally disbursed. Ecological taxes according to EU are defined as tax forms whose basis is expressed in the physich units of materia and the negative impact they have in the environment.

Successful projection and implementation guarantees a sustainable tax system. This within itself contains the good governance along with possession of human resources prepared to execute these policies.

A desirable governance should be based in the coherence between different objectives and policies and in the creation of an environment where subjects will be treated equally. Thus this duty that is considered public in the sphere of financial management requires fiscal transparency, responsibility, accountability or qualitative activities constantly directed towards the future.

To this approach there should be carefully added the creation of a culture of behaviour conform public interest. Achievement of this culture requires a long, continual and gradual process of changing the values. Absence of such culture will not have trust to government and it will be difficult to convince citizens to pay required taxes.

\section{References}

Baldwin, R. and Wyplosz, Ch., The Economics of European Integration, New York: The McGraw-Hill, 2006;

Barry, F.: Fiscal Policy in EMU, UE. Pentecost \& van Poeck, A. (ed.), European Monetary Integration, Aldershot: Edvard Elgar, 2001

Code of Conduct for Business Taxation, OJ C 2, 6.1.1998;

D. Pîrvu i E. Clipici, Perspectives of the Environmental Taxes Evolution in the European Union, The Romanian Economic Journal, No. 38., December, 2012

Filipović, S., Ekonomski anali br 162, jul 2004. - Septembar 2004

Eichengreen, B.: Institution for Fiscal Stability, Working Paper PEIF-14, Berkeley: Institute of European Studies, 2003;

Eichengreen, B. \& von Hagen, J.: Fiscal Policy and Monetary Union: Is there a Tradeoff Between Federalism and Budgetary Restrictions? NBER Working Paper, WP/5517, 1996b;

European Commission: A European Economic Recovery Plan, Novembar, 2008; European Commission: European Union Public Finance, European Communities, Brussels, 2002;

European Commission: The European Union Budget at a glance, European Communities, Brussels, 2007; European Council, 1997 i $1997 \mathrm{~b}$;

European Tax Handbook 2006., IBFD, Amsterdam, 2006; European Environment Agency - Environmental tax reform in Europe: opportunities for eco-innovation, Luxembourg: Publications Office of the European Union, 2011

EU Taxation, (2005a), Common taxation of parentcompanies and their subsidiaries [http://www.europa.eu. int/scadplus/leg/en/lvb/l26037.htm];

Klarer i drugi: Sourcebook on Economic Instruments for Environmental Policy Central and Eastern Europe, The Regional Environmental Center for Central and Eastern Europe, Szentendre, Hungary,

Kokonozi Arijana "Zbatimi i ligjit per mbrojtjen e mjedisit" IMIM marrë në http://www.justforumalbania.org/zbatimi-i-ligjit-per-mbrojtjen-e-mjedisitt83.html

Stiglic, E. Joseph, Ekonomija javnog sektora, Ekonomski fakultet, Zagreb, 2004

Shoqëria dhe Mjedisi i saj - Botim i Qendres Rajonale të Mjedisit për Evropën Qendrore dhe Lindore - Zyra në Kosovë / Titulli origjinal: Society and Its Environment an Introduction - Egbert Tellegen and Maarten Wolsink, University of Amsterdam, the Netherlands Publisher: Gordon and Breach Science Publishers Amsteldijk 166, 1st Flor 1079 LH Amsterdam The Netherlands 